\title{
HUBUNGAN GAYA KOGNITIF, KECERDASAN EMOSIONAL DENGAN PRESTASI BELAJAR FISIKA SISWA IPA SMA KRISTEN BARANA RANTEPAO TORAJA
}

\author{
Yulia Sanang \\ Alumni Program Studi Magister Manajemen Pendidikan \\ FKIP-Universitas Kristen Satya Wacana \\ J.T.Lobby Loekmono \\ Program Studi S1 Bimbingan \& Konseling \\ FKIP-Universitas Kristen Satya Wacana
}

\begin{abstract}
ABSTRAK
Penelitian korelasional ini dilakukan dengan tujuan untuk: mengetahui signifikansi hubungan gaya kognitif dan kecerdasan emosional dengan prestasi belajar fisika pada siswa SMA Kristen Barana yang melibatkan 135 orang siswa jurusan IPA. Pengumpulan data pada penelitian ini mengunakan instrument The Embedded Figure Test untuk mengukur variabel gaya kognitif dan Bar on Inventory untuk mengungkap kecerdasan emosional sedang analisis datanya menggunakan uji korelasional Rank Spearman. Hasil analisis menunjukkan bahwa ada hubungan signifikan antara gaya kognitif dengan prestasi belajar fisika $r_{x y}=0,257$ dengan $p=0,003<0,05$ dan tidak ada hubungan signifikan antara kecerdasan emosional dengan prestasi belajar fisika peserta didik IPA di SMA Kristen Barana dengan koefisien $r_{x y}=0,053$ dengan $\mathrm{p}=0,541>0,05$.
\end{abstract}

Kata kunci: Gaya kognitif, Kecerdasan Emosional dan Prestasi Belajar Fisika

\section{PENDAHULUAN}

Peningkatan manajemen mutu pendidikan di sekolah adalah kebutuhan yang perlu dipenuhi. Manajemen pendidikan terdiri dari dimensi proses dan substansi. Dimensi proses mencakup perencanaan, pelaksanaan, dan evaluasi pendidikan. Sedangkan pada tataran substansi meliputi personalia, keuangan, sarana dan prasarana, serta instrumen pembelajaran. Sekolah diharapkan memikirkan proses apa yang sebaiknya dilalui oleh peserta didik agar menghasilkan lulusan (output) yang baik. Proses itu dapat berupa penentuan metode pembelajaran yang tepat untuk tiap peserta didik dengan tidak mengesampingkan bahwa tiap peserta didik memiliki kemampuan dan karakteristik yang berbeda-beda. Proses pembelajaran yang baik akan menunjang keberhasilan belajar tiap peserta didik. Prestasi belajar merupakan salah satu bukti yang menunjukkan pencapaian (kompetensi) seseorang setelah melakukan proses belajar sesuai dengan bobot atau nilai yang berhasil diperoleh (Winkel, 1996). Karakteristik siswa salah satunya adalah gaya kognitif.

Witkin (1971) merumuskan gaya kognitif sebagai cara berfungsi diri (self) yang tetap yang ditunjukkan/dinampakkan oleh seseorang dalam kegiatan/aktivitas persepsi dan inteleknya. Gaya kognitif berkaitan dengan bentuk, bukan isi kegiatan kognitif. Gaya kognitif menunjuk pada perbedaan individu dalam aspek melihat, berpikir, menyelesaikan masalah, belajar, dan dalam berhubungan dengan orang lain. 
SMA Kristen Barana Rantepao adalah sekolah unggulan di Toraja Utara. Pada tahun ajaran 2012-2013 sekolah ini memiliki siswa sebanyak 320 orang siswa. Dalam pra penelitian dengan 43 orang peserta didik di kelas IPA ditemukan bahwa 72,1 persen peserta didik memiliki gaya kognitif field dependent (FD) yang cocok belajar ilmu pengetahuan sosial sedangkan 27,9 persen peserta didik memiliki gaya kognitif field independent (FI) yang cocok belajar ilmu pengetahuan alam sebagaimana tergambar pada tabel 1 .

Tabel 1. Persentase Gaya Kognitif Peserta Didik di SMA Kr Barana Rantepao Toraja Utara

\begin{tabular}{ccc}
\hline $\begin{array}{c}\text { Kategori } \\
\text { Gaya Kognitif }\end{array}$ & $\begin{array}{c}\text { Jumlah peserta didik } \\
\text { (orang) }\end{array}$ & $\begin{array}{c}\text { Presentase } \\
(\%)\end{array}$ \\
\hline FI & 12 & $27,9 \%$ \\
FD & 31 & $72,1 \%$ \\
\hline
\end{tabular}

Sumber data SMA Kr Barana Rantepao Toraja Utara

$*)=($ peserta didik /total peserta didik)x $100 \%$

Tabel 2. Nilai UN SMA Kr Barana

\begin{tabular}{|c|c|c|c|c|c|c|c|c|c|c|c|c|}
\hline \multirow{2}{*}{ Nilai UN } & \multicolumn{4}{|c|}{ Tahun 2009-2010 } & \multicolumn{4}{|c|}{ Tahun 2010-2011 } & \multicolumn{4}{|c|}{ Tahun 2011-2012 } \\
\hline & MTK & Kimia & Biologi & Fisika & MTK & Kimia & Biologi & Fisika & MTK & Kimia & Biologi & Fisika \\
\hline Rat-rata & 8,94 & 9,33 & 8,94 & 8,73 & 9,67 & 9,41 & 8 & 9,56 & 9,73 & 9,13 & 8,15 & 7,82 \\
\hline
\end{tabular}

Sumber data SMA Kr Barana Rantepao

*MTK $=$ Matematika

Pada sisi lain tabel 2 memperlihatkan hasil Ujian Nasional di sekolah SMA Kr Barana yang menunjukkan ada kenaikan dan penurunan nilai UN. Pada tahun 2011 terjadi kenaikan nilai UN Fisika dan di tahun 2012 terjadi penurunan.

Tabel 3. Persentase Kecerdasan Emosional Peserta didik di SMA Kr Barana

\begin{tabular}{lccc}
\hline $\begin{array}{c}\text { Kategori } \\
\text { Kecerdasan Emosional }\end{array}$ & Range & $\begin{array}{c}\text { Jumlah siswa } \\
\text { (orang) }\end{array}$ & $\begin{array}{c}\text { Persentase } \\
(\%)\end{array}$ \\
\hline Rendah & $128-229$ & 0 & 0 \\
Di bawah rata-rata & $230-331$ & 1 & 2,31 \\
Rata-rata & $332-433$ & 19 & 44,23 \\
Di atas rata-rata & $434-535$ & 21 & 48,84 \\
Tinggi & $536-640$ & 2 & 4,62 \\
\hline
\end{tabular}

Sumber data SMA Kr Barana Rantepao Toraja Utara

* $)=($ peserta didik /total peserta didik $) \times 100 \%$

Berdasarkan temuan-temuan di atas, maka penelitian ini ingin melihat apakah ada hubungan yang signifikan antara kecerdasan emosional dengan prestasi belajar fisika peserta didik di SMA Kr Barana Rantepao. 


\section{LANDASAN TEORI}

\section{Pengertian Prestasi Belajar Fisika}

Prestasi belajar fisika adalah proses yang dilakukan individu dalam kegiatan belajar, biasanya dinyatakan dalam bentuk nilai atau indeks prestasi yang diperoleh dari hasil pengukuran prestasi belajar (Widyastuti \& Kuswardani, 2008). Prestasi belajar adalah hasil yang dicapai seseorang dalam belajar. Prestasi belajar dalam bentuk nilai diperoleh melalui hasil pengukuran proses belajar (Surya, 2004). Slameto (2002) mendefinisikan prestasi belajar sebagai performan dan kompetensinya dalam mata pelajaran setelah mempelajari materi untuk mencapai tujuan pengajaran tertentu dalam satu satuan waktu.

Prestasi belajar fisika adalah hasil pencapaian belajar yang diperoleh dalam mencapai kompetensi yang telah ditetapkan yang dinyatakan dalam skor/nilai yang diperoleh dari serangkaian tes/ulangan. Kompetensi yang dimaksudkan telah diatur dalam Standar Kompetensi Lulusan (SKL) yang dijabarkan dalam bentuk Standar Kompetensi (SK) dan SK dijabarkan dalam bentuk kompetensi dasar (KD). Siswa belajar untuk mencapai SKL yang telah ditetapkan. Kompetensi tersebut dapat dilihat dari standar kompetensi dan kompetensi dasar yang telah ditetapkan dan diintegrasikan dalam indikator-indikator. Standar kompetensi (SK) dan Kompetensi dasar (KD) berbeda ditiap tingkatan kelas dan mata pelajaran yang saling berkesinambungan. SK dan KD dirumuskan oleh Dekdikbud pusat secara nasional dan guru mata pelajaran merumuskannya dengan indikator dan tujuan pembelajaran.

\section{Faktor-faktor yang mempengaruhi Prestasi Belajar Fisika}

Witkin (1977) menyatakan faktor yang mempengaruhi prestasi belajar yaitu gaya kognitif. Gaya kognitif merupakan cara siswa yang khas dalam belajar, baik yang berkaitan dengan cara penerimaan dan pengolahan informasi, sikap terhadap informasi, maupun kebiasaan yang berhubungan dengan lingkungan belajar. Individu dengan gaya kognitif Field Independent lebih cenderung/ lebih mudah menguasai pelajaran sains dan matematika sedangkan individu dengan gaya kognitif Field Dependent cenderung menguasai ilmu pengetahuan sosial (Laurdusamy, 1994).

Surya (2004) menyatakan bahwa inti dari seluruh kegiatan pendidikan terletak pada proses kegiatan belajar mengajar, kegiatan belajar mengajar berlangsung melalui interaksi antar peserta didik dan guru, sehingga Surya (2004) membagi empat aspek penting dalam proses belajar mengajar berupa: (a) perilaku belajar siswa sendiri, (b) perilaku mengajar guru, (c) interaksi antara pengajar dan anak didik, dan (d) model pembelajaran. Perilaku belajar siswa dapat berupa gaya belajar atau gaya kognitif siswa sedangkan interaksi peserta didik dengan guru dan sesamanya dapat berupa kecerdasan emosionalnya. Slameto (2003) menyebutkan faktor-faktor yang mempengaruhi prestasi belajar siswa adalah faktor jasmani, faktor psikologis, faktor kelelahan, faktor keluarga, faktor sekolah dan faktor masyarakat.

\section{Pengukuran Prestasi Belajar Fisika}

Mengukur prestasi belajar fisika mengunakan tes prestasi belajar yang dibuat oleh guru mata pelajaran. Tes prestasi ini dibuat untuk mengukur kompetensi dasar peserta didik, apabila satu kompetensi dasar selesai dipelajari maka dapat diukur dengan tes prestasi baik tes lisan, tertulis maupun praktik. Prestasi belajar fisika diperoleh dengan menggunakan persamaan $(2 \mathrm{xUH})+\mathrm{UTS}+\mathrm{S}) /$ 4. Dimana UH adalah ulangan harian, UTS adalah ulangan tengah semester dan $\mathrm{S}$ adalah semester. 


\section{GAYA KOGNITIF}

\section{Pengertian gaya kognitif}

Menurut Witkin (1977) gaya kognitif adalah cara berfungsi karakteristik yang tetap yang ditunjukkan oleh seorang individu dalam aktivitas-aktivitas persepsi dan inteleknya untuk menentukan kebiasaan seseorang menanggap, mengingat, berfikir dan menyelesaikan masalah. Ada empat ciri gaya kognitif yang penting yaitu:

1. Gaya kognitif berkaitan dengan bentuk bukan dengan isi kognitif. Gaya kognitif melihat perbedaan individu dalam aspek berfikir, menyelesaikan masalah, belajar, dan berhubungan dengan orang lain.

2. Gaya kognitif sebagai suatu dimensi yang meresap. Gaya Kognitif adalah penemuan bertaraf tinggi yang mengatur dan mengikuti perilaku dalam berbagai situasi yang berbeda.

3. Gaya kognitif adalah stabil sepanjang masa. Gaya kognitif berkembang perlahan-lahan mengikut pengalaman. Gaya kognitif tidak dapat digantikan dengan mudah melalui pengajaran atau latihan tertentu, tetapi dapat berubah mengikuti kematangan.

4. Gaya kognitif bersifat dwipolar. Ciri ini dapat membedakan konsep gaya kofnitif dengan kecerdasan dan dimensi keterampilan yang lain. Setiap gaya kognitif mempunyai nilai adaptif mengikuti keadaan-keadaan tertentu. Oleh karena itu setiap pola gaya kognitif dapat dianggap pasif bila berkaitan dengan keadaan tertentu.

Ada 10 gaya kognitif yang menurut Witkin (1997) sering dijadikan bahan penelitian, kesepuluh gaya tersebut adalah:

1. Field independent lawan field dependent adalah gaya kognitif yang tetap dalam menghadapi alam sekitar secara analitik atau secara global. Gaya kognitif ini membedakan gaya kognitif peserta didik yang dominan ke sains dan sosial.

2. Gaya pengkonsepan satu atau multi jenis rangsangan adalah gaya kognitif yang ciri individualnya tetap dalam menggunakan suatu jenis rangsangan tertentu atau multi jenis rangsangan dalam hubungannya sebagai dasar untuk membentuk konsep.

3. Membentuk kategori secara luas lawan secara sempit, adalah gaya kognitif yang kecenderungannya memasuki sesuatu secara luas berbanding dengan kecenderungan memasuki secara sempit dalam proses pembentukan kategori yang spesifik.

4. Mengkategorikan rangsangan dari persamaan lawan perbedaan, adalah gaya kognitif yang membedakan individu dalam kecenderungan mengkategorikan tanggapan tentang persamaan dan perbedaan yang dilihat diantara rangsangan-rangsangan dari banyak konsep yang berbeda.

5. Meratakan lawan menajamkan adalah gaya kognitif yang membedakan individu dalam proses asimilasi ingatan.individu yang bersifat meratakan cenderung mengaburkan ingatan-ingatan yang serupa, sedangkan individu yang menajamkan sebaliknya.

6. Keluasan lawan kesungguhan (scanning), adalah gaya kognitif yang membedakan individu dari keluasan dan kesungguhan memberikan perhatian yang mengakibatkan perbedaan individual dalam pengalaman dan kesadaran.

7. Merefleks lawan Bertindak spontan adalah gaya kognitif yang membedakan individu dari kecepatan dan ketepatan merespon sebuah proses yang terjadi.

8. Mengambil risiko lawan Berhati-hati adalah gaya kognitif yang membedakan individu dari kesediaan individu mengambil risiko untuk mencapai apa yang diinginkan berbanding kecenderungan mencari kepastian dan menghindari situasi yang berisiko. 
9. Toleransi untuk pengalaman yang unik lawan konvensional, adalah gaya kognitif yang membedakan individu dari segi kesediaan menerima presepsi dan ide-ide yang berlainan dengan pengalaman konvensional.

10. Pemikiran konvergen lawan pemikiran divergen adalah gaya kognitif yang membedakan individu berdasarkan kesimpulan yang logik dan paling betul atau kesimpulan yang terbaik mengikuti kebiasan (pemikiran konvergen) berbanding dengan mencapai hal yang beragam (pemikiran divergen).

Penelitian ini menggunakan variabel gaya kognitif Field Independent dan Field Dependent.

\section{Gaya kognitif Field Independent (FI) dan Field Dependent (FD)}

Gaya kognitif merupakan cara individu yang khas dalam belajar, baik yang berkaitan dengan cara penerimaan dan pengolahan informasi, sikap terhadap informasi, maupun kebiasaan yang berhubungan dengan lingkungan belajar (Witkin, 1977). Witkin menyatakan bahwa: "orang mempunyai gaya kognitif 'field-independent' merespon suatu tugas cenderung berdasarkan atau berpatokan pada syarat-syarat dari dalam diri sendiri. Sedangkan orang memliki gaya kognitif 'field-dependent' melihat syarat lingkungan sebagai petunjuk dalam merespon suatu stimulus" lebih lanjut Witkin (1978) menyatakan bahwa: “orang memiliki gaya kognitif 'field-independent' lebih bersifat kritis, mereka dapat memiliki stimulus berdasarkan situasi, sehingga persepsinya hanya sebagian kecil terpengaruh ketika ada perubahan situasi. Sedangkan orang yang memiliki gaya kognitif 'field-dependent' mengalami kesulitan dalam membedakan stimulus melalui situasi yang dimiliki sehingga persepsinya mudah dipengaruhi oleh manipulasi dari situsi sekelilingnya". Pendapat serupa yang dikemukakan oleh Witkin (1977) juga mengatakan bahwa: "orang yang memiliki gaya kognitif 'field-independent' lebih suka memisahkan bagian-bagian dari sejumlah pola dan menganalisis pola berdasarkan komponen-komponennya. Sedangkan orang yang memiliki gaya kognitif 'field-dependent' cenderung memandang suatu pola sebagai keseluruhan tidak memisahkan ke dalam bagian-bagiannya.

Berdasarkan pendapat Witkin (1977), bahwa orang yang memiliki gaya kognitif 'fieldindependent' mempunyai kecenderungan dalam merespons stimulus menggunakan persepsi yang dimilikinya sendiri, lebih analitis, dan menganalisis pola berdasarkan komponen-komponennya. Sedangkan orang yang memiliki gaya kognitif 'field-dependent' mempunyai kecenderungan dalam merespons suatu stimulus menggunakan syarat lingkungan sebagai dasar dalam persepsinya, dan kecenderungan memandang suatu pola sebagai keseluruhan, tidak memisahkan bagian-bagiannya.

Faktor-faktor sosial merupakan faktor penting dalam proses perkembangan perbedaan berkaitan dengan gaya kognitif FI - FD. Kajian tentang pengalaman keluarga saat anak-anak yang mempunyai ciri field-independent (FI) atau field-dependent (FD) secara relatif menunjukkan bahwa keadaan hubungan seorang anak yang sedang bertumbuh dengan ibunya dipengaruhi dalam menentukan gaya kognitifnya. Ciri-Ciri Gaya Kognitif FI - FD melibatkan cara menanggap alam sekeliling secara analisis berlawanan dengan cara global. Misalnya, apabila diberi suatu bentuk geometrik mudah yang disembunyikan dalam suatu bentuk kompleks, individu FI akan lebih cepat dapat menemukan bentuk mudah itu dari lingkungan kompleksnya, sedangkan individu yang global atau FD akan menghadapi kesukaran melakukan kegiatan ini.

Individu atau siswa FD dan FI tidak terlalu berbeda dari segi kemampuan pembelajaran atau ingatan. Tetapi mereka lebih terpengaruh oleh isi materi dan cara pengajaran. Siswa FD biasanya menunjukkan kemampuan lebih baik dalam pembelajaran dan dapat mengingat bahan-bahan yang 
mempunyai isi materi berkaitan dengan sosial. Kelebihan ini bergantung pada kebolehan mereka memberikan perhatian utama kepada bidang sosial. Sebaliknya prestasi individu FI tidak terlalu baik pada materi-materi yang berbentuk sosial karena mereka kurang memberikan perhatian kepada materi berbentuk sosial. Lourdusamy(1994) membedakan FI dan FD seperti pada tabel 4.

Tabel 4. Perbedaan FI dan FD menurut Lourdusamy(1994)

\begin{tabular}{ll}
\hline FI (Field independent) & FD (Field Dependent) \\
\hline 1. Cenderung pada struktur analisis & Cenderung pada konteks sosial \\
2. Tidak menyukai hubungan interpersonal & Lebih menyukai hubungan interpersonal \\
3. Bidang-bidang yang dipilih: & bidang-bidang yang dipilih: \\
-Matematika & -Kemanusiaan \\
-Fisika & -Bahasa \\
-Kimia & -Agama \\
-Biologi & -Pemasaran \\
-Pertaniaan & -Psikologi \\
-Sains dan Matematika & - konseling \\
\hline
\end{tabular}

Siswa yang memiliki gaya kognitifFI dan masuk dalam kelas IPA akan lebih mudah menguasai materi IPA seperti fisika dan sebaliknya. Jika siswa ada di kelas IPA dan di dukung oleh gaya kognitif yang tepat yaitu FI maka siswa tersebut dapat meningkatkan prestasi belajar fisikanya.

\section{Mengukur Gaya Kognitif}

Mengukur gaya kognitif tidak dapat dilakukan dengan mengobservasi, karena mengukur gaya kognitif akan melihat kecenderungan dalam merespons stimulan dan menganalisisnya (Witkin 1977). Beberapa tes yang dapat mengukur gaya kognitif adalah GEFT(Group Embedded Figure Test), MFFT (Matching Familiar Figure Test yang membedakan gaya kognitif Reflectife atau impulsive), RFT ( Rod and Frame Test), dan perangkat tes Profil gaya kognitif yang dikembangkan oleh NASSP (National Association of Secondary School Principals). Alat ukur yang digunakan dalam penelitian ini adalah yang disusun oleh Witkin dan kawan-kawan adalah The Embedded Figure Test (EFT). Dalam tes ini individu mencari sebuah gambar yang sederhana yang sebelumnya diperlihatkan sebuah gambar yang kompleks yang lebih besar yang diorganisasikan sedemikian rupa sehingga membaurkan gambar yang akan dicari. EFT akan mencerminkan tingkat kompetensi di persepsi pemisahan gambar. Individu yang field independent akan lebih mudah menemukan gambaran sederhana dari gambar kompeks yang disediakan sebaliknya dengan individu field dependent.

\section{Kecerdasan Emosional}

Salovey dan Mayer (1990) mendefinisikan Kecerdasan emosional sebagai bentuk kecerdasan yang melibatkan kemampuan memonitor perasaan dan emosi yang dimiliki individu atau emosi orang lain untuk membedakan diantara mereka dan menggunakan informasi tersebut untuk menentukan pikiran dan tindakan seseorang (Davis 2008). Salovey dan Mayer (1990) adalah dua psikolog yang pertama kali menggunakan pandangan yang menyatakan bahwa emosi sebenarnya adalah sejenis informasi yang kemudian membentuk munculnya konsep kecerdasan di tahun 1990. Pendekatan yang digunakan Salovey dan Mayer (1990) adalah ada sejumlah kecil kemampuan 
khusus yang dimiliki seseorang yang berhubungan dengan ketelitian terhadap perasaan dan pengertian keadaan emosi pada diri seseorang dan orang lain serta keefektifan terhadap pengaturan, pengendalian dan dan dalam menggunakan emosi untuk memcapai sasaran seseorang. Ada tiga aspek utama kecerdasan emosional menurut Salovey dan Mayer (1997) yaitu penilaian dan ekspresi emosi, pemanfaatan emosi, dan regulasi emosi.

Menurut Goleman (1995), kecerdasan emosional adalah kemampuan seseorang mengatur kehidupan emosinya dengan inteligensi (to manage our emotional life with intelligence); menjaga keselarasan emosi dan pengungkapannya (the appropriateness of emotion and its expression) melalui keterampilan 1) kesadaran diri, 2) pengendalian diri, 3) motivasi diri, 4) empati dan 5) keterampilan sosial. Goleman mengembangkan dan memperluas pengertian tentang kecerdasan emosi yang telah dilakukan oleh Salovey dan Mayer (1990).

Goleman (2000) mengatakan bahwa ada kecerdasan lain selain kecerdasan intelektual yaitu kecerdasan emosi, yang dimaksud dengan kecerdasan emosi di dalamnya termasuk kemampuan mengontrol diri, memacu, tetap tekun, serta dapat memotivasi diri sendiri. Kecakapan tersebut mencakup pengelolaan bentuk emosi baik yang positif maupun negatif. Kecerdasan emosional merupakan kemampuan yang dimiliki seseorang untuk menerima, menilai, mengelola, serta mengontrol emosi dirinya dan orang lain di sekitarnya. Emosi mengacu pada perasaan seseorang terhadap informasi akan suatu hubungan. Sedangkan, kecerdasan (intelligence) mengacu pada kapasitas untuk memberikan alasan yang valid akan suatu hubungan.

Goleman (1995) menyatakan bahwa koordinasi suasana hati adalah inti dari hubungan sosial yang baik. Apabila seseorang pandai menyesuaikan diri dengan suasana hati individu yang lain atau dapat berempati, orang tersebut akan memiliki tingkat emosionalitas yang baik dan akan lebih mudah menyesuaikan diri dalam pergaulan sosial serta lingkungannya. Lebih lanjut Goleman (1995) mengemukakan bahwa kecerdasan emosional adalah kemampuan lebih yang dimiliki seseorang dalam memotivasi diri, ketahanan dalam menghadapi kegagalan, mengendalikan emosi dan menunda kepuasan, serta mengatur keadaan jiwa.

Dengan kecerdasan emosional seseorang dapat menempatkan emosinya pada porsi yang tepat, memilah kepuasan dan mengatur suasana hati. Daniel Goleman (Emotional Intelligence) menyebutkan bahwa kecerdasan emosi jauh lebih berperan ketimbang IQ atau keahlian dalam menentukan siapa yang akan jadi bintang dalam suatu pekerjaan.

Salovey dan Mayer (1997) menyatakan bahwa ada empat aspek dasar kecerdasan emosi yaitu mengenali emosi, memahami emosi, mengatur emosi dan menggunakan emosi( Davis, 1997) yang merupakan pengembangan dari penemuan mereka ditahun 1990.

Baron di tahun 1997 menyusun instrument yang dinamakan Bar-On inventory membagi kecerdasan emosional dalam lima skala dan kemudian membaginya dalam 15 sub skala. 5 skala tersebut adalah 1) interpersonal, 2) intrapersonal, 3) adaptasi, 4) manejemen stres dan 5) suasana hati. Sedangkan 15 subskalanya adalah: Kesadaran diri, ketegasan, penilaian diri, aktualisasi diri, kemandirian, empati, hubungan interpersonal, tanggung jawab sosial, memecahkan masalah, menguji realitas, fleksibilitas, toleransi stres, kontrol impluse, kebahagiaan dan optimis.

Ada dua faktor yang mempengaruhi kecerdasan emosional yaitu faktor ekternal dan faktor internal (Goleman, 2000). Faktor internal adalah apa yang ada dalam diri individu yang mempengaruhi kecerdasan emosinya. Faktor internal ini memiliki dua sumber yaitu segi jasmani dan segi psikologis. Segi jasmani adalah faktor fisik dan kesehatan individu, apabila fisik dan kesehatan seseorang dapat terganggu dapat dimungkinkan mempengaruhi proses kecerdasan 
emosinya. Segi psikologis mencakup di dalamnya pengalaman, perasaan, kemampuan berfikir dan motivasi. Faktor ekstemal adalah stimulus dan lingkungan dimana kecerdasan emosi berlangsung. Faktor ekstemal meliputi: 1) Stimulus itu sendiri, kejenuhan stimulus merupakan salah satu faktor yang mempengaruhi keberhasilan seseorang dalam memperlakukan kecerdasan emosi tanpa distorsi dan 2) Lingkungan atau situasi khususnya yang melatarbelakangi proses kecerdasan emosi. Objek lingkungan yang melatarbelakangi merupakan kebulatan yang sangat sulit dipisahkan.

\section{Aspek-aspek Kecerdasan Emosional}

Menurut Gardner (1983) terdapat lima pokok utama dari kecerdasan emosional seseorang, yakni mampu menyadari dan mengelola emosi diri sendiri, memiliki kepekaan terhadap emosi orang lain, mampu merespon dan bernegosiasi dengan orang lain secara emosional, serta dapat menggunakan emosi sebagai alat untuk memotivasi diri. Goleman (1995) menyatakan kemampuan individu dalam mengelola emosinya akan membantu kesuksesan di masa datang. Terdapat 5 aspek utama dalam kecerdasan emosional yaitu:

a. Kesadaran diri (self-awareness) yaitu kemampuan individu untuk menyadari dan memahami keseluruhan proses yang terjadi di dalam dirinya, perasaannya, pikirannya, dan latar belakang tindakannya. Mayer menyatakan kesadaran diri adalah waspada terhadap suasana hati maupun pikiran tentang suasana hati, bila kurang waspada maka individu menjadi muda larut dalam aliran emosi dan dikuasai oleh emosi. Kesadaran diri adalah sesuatu yang diperlukan untuk mengendalikan emosi seseorang (Goleman 2002).

b. Kemampuan mengelola emosi (managing emotions) yaitu kemampuan individu untuk mengelola dan menyeimbangkan emosi-emosi yang dialaminya. ini meliputi kemampuan seseorang dalam menghibur dirinya sendiri, melepaskan kecemasan maupun rasa tersinggung ataupun kemampuan untuk bangkit dari perasaan yang menekan diri orang tersebut. Empati juga merupakan kemampuan untyk mengenali emosi orang lain yang ditunjukkan seseorang dalam bentuk kepedulian. seseorang yang memuliki empati yang tinggi mengetahui apa yang dibutuhkan orang lain sehingga peka terhadap perasaaan dan kebutuhan orang lain sehingga lebih mampu mendengarkan orang lain.

c. Optimisme (motivating oneself) yaitu kemampuan individu untuk memotivasi diri ketika berada dalam keadaan putus asa, dapat berpikir positif, dan menumbuhkan optimisme dalam hidupnya.

d. Empati (empaty) yaitu kemampuan individu untuk memahami perasaan, pikiran, dan tindakan orang lain dari sudut pandang orang lain.

e. Keterampilan sosial (social skill) yaitu kemampuan individu untuk membangun hubungan secara efektif dengan orang lain, mampu mempertahankan hubungan sosial tersebut dan mampu menangani konflik-konflik interpersonal secara efektif.Goleman (2002) beranggapan kemampuan dalam membina hubungan adalah keterampilan yang akan menunjang popularitas, kepemimpinan dan keberhasilan antar pribadi. Keterampilan dalam berkomunikasi adalah kemampuan dasar yang menentukan keberhasilan membina hubungan. Goleman( 2002) berpendapat bahwa orangorang akan populer dalam lingkungan dan menjadi orang yang menyenangkan karena kemampuannya dalam berkomunikasi.

Kelima aspek tersebut digunakan sebagai komponen utama dari kecerdasan emosional sebagai faktor untuk menggembangkan instrumen kecerdasan emosional. 


\section{Mengukur Kecerdasan Emosional}

Ada 6 alat ukur dalam menggukur kecerdasan emosional individu. Alat ukur tersebut berupa test atau inventori dan skala seperti Trait MetaMood Scale (Salovey, 1995), BarOn Emotional Quotient Inventory (Baron, 2003), Schutte Emotional Intelligence Scale (Schutte, 1998), Emotional Competence Inventory (Boyatzis, 1999), Emotional Intelligence IPIP Scales (Barchard, 2001), dan Emotional Intelligence Self Regulation (Martinezpons, 2000). Pada penelitian ini akan di gunakan Bar on Inventory yang di kembangkan oleh Reuven Baron.

Bar on Inventori ini berisi 5 skala dan 15 subskala dengan total 128 item (Baron, 2003). Baron membagi kecerdasan emosional dalam 5 kategori seperti pada berikut:

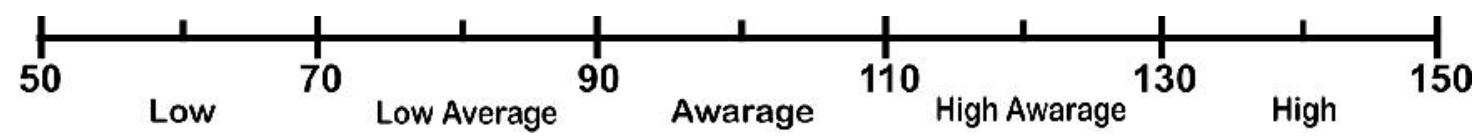

$$
\begin{array}{ll}
\text { Kategori } 1 \text { skor } 50-69 & =\text { rendah } \\
\text { Kategori } 2 \text { skor } 70-89 & =\text { di bawah rata-rata } \\
\text { Kategori } 3 \text { skoe } 90-109 & =\text { rata-rata } \\
\text { Kategori } 4 \text { skor } 110-129 & =\text { di atas rata-rata } \\
\text { Kategori } 5 \text { skor } 130-150 & =\text { tinggi }
\end{array}
$$

\section{METODE PENELITIAN}

Penelitian ini merupakan penelitian korelasional, penelitian korelasional meneliti hubungan antara variabel dan menguji hipotesis yang sudah dibuat (Hasan, 2002). Penelitian dilaksanakan di SMA Kr Barana (R-SMA-BI) Rantepao Toraja Utara dengan alamat J1. Pamabi Barana Rantepao Toraja Utara. Populasi pada penelitian ini adalah peserta didik kelas IPA kelas XI dan XII IPA di SMA Kr Barana (RSBI) Rantepao Tana Utara dengan 143 orang siswa. Pada tabel penentuan jumlah sampel dari populasi tertentu dengan tingkat kesalahan 1 persen didapat nilai sampel minimal 122. Sampel yang akan digunakan pada penelitian ini sebanyak 135 orang. Teknik Pengumpulan Data dalam penelitian ini diambil dalam dua bagian. Data pertama dengan mengunakan instument test The Embedded Figures Test yang disusun oleh Witkin (1977) untuk mengukur gaya kognitif peserta didik dan Bar-on Inventory untuk mengukur kecerdasan emosional peserta didik dan data kedua dengan menggunakan nilai prestasi belajar fisika pada akhir semester gasal tanpa remidial.

Data yang diperoleh akan dianalisis dengan analisis deskriptif dan analisis Korelational. Analisis deskriptif digunakan untuk mengetahui gambaran tentang hasil pengukuran gaya kognitif dan kecerdasan emosi dengan prestasi belajar peserta didik. Dalam analisis deskriptif ukuran yang digunakan adalah mean, standar deviasi, skor minimum dan skor maksimum. Analsis korelasi digunakan untuk menguji hipotesis, yaitu korelasi antara gaya kognitif $\left(\mathrm{X}_{1}\right)$ dan Kecerdasan emosi $\left(\mathrm{X}_{2}\right)$ dengan prestasi belajar $\left(\mathrm{Y}_{1}\right)$ dan prestasi belajar fisika $\left(\mathrm{Y}_{2}\right)$ menggunakan teknik korelasi Rank Spearman. 


\section{Analisis deskriptif}

\section{Gaya Kognitif}

Dari penelitian yang dilakukan didapatkan hasil seperti pada tabel 5 berikut ini,

Tabel 5. Prosentase responden berdasarkan Gaya Kognitif

\begin{tabular}{ccccc}
\hline Jumlah & \multicolumn{4}{c}{ Gaya Kognitif } \\
\cline { 2 - 5 } Siswa(org) & Field Independent (org) & $\%$ & Field Dependent (org) & $\mathbf{\%}$ \\
\hline 135 & 27 & 20 & 108 & 80 \\
\hline
\end{tabular}

Sumber data SMA Kr Barana Rantepao Toraja Utara

*) $=($ peserta didik /total peserta didik) $\times 100 \%$

Dari tabel 5, terlihat bahwa sebagian besar responden mempunyai gaya kognitif FD $=80$ persen yaitu gaya kognitif yang lebih cocok untuk belajar di bidang IPS sedangkan yang memiliki gaya kognitif FI yang lebih cocok belajar dibidang IPA hanya 20 persen. Dengan kata lain peserta didik yang ada dikelas IPA 80 persen adalah anak-anak yang memiliki kemampuan yang lebih cocok di bidang IPS.

\section{Kecerdasan Emosional}

Dari pengisian Bar on Inventory diperoleh hasil seperti pada tabel 6 berikut:

Tabel 6. Kategori Kecerdasan Emosional

\begin{tabular}{clcc}
\hline Skor & \multicolumn{1}{c}{ Kategori } & $\begin{array}{c}\text { Jumlah } \\
\text { (orang) }\end{array}$ & $\%$ \\
\hline $50-70$ & Rendah & 0 & 0 \\
$71-90$ & Di bawah rata-rata & 1 & 0,74 \\
$91-110$ & Rata-rata & 60 & 44,44 \\
$111-130$ & Di atas rata-rata & 72 & 53,33 \\
$131-150$ & Tinggi & 2 & 1,48 \\
\hline & Total & 135 & 100 \\
\hline
\end{tabular}

Sumber data SMA Kr Barana Rantepao Toraja Utara

*) $=($ peserta didik /total peserta didik) $\mathrm{x} 100 \%$

Dari tabel 6, terlihat bahwa sebagian besar siswa IPA mempunyai Kecerdasan emosional pada kategori Di atas rata-rata (53,33\%). Artinya kecerdasan emosional siswa IPA SMA Kr Barana di atas rata-rata dibandingkan anak sebaya di sekolah lain (SMA) di indonesia.

\section{Prestasi belajar Fisika}

Hasil prestasi belajar fisika peserta didik yang diambil dari nilai ulangan harian(ulangan blok), mid semester dan semester ganjil sebelum remidial. KKM untuk mata pelajaran Fisika adalah 76. Dari 135 orang hanya 50 orang yang tuntas memenuhi KKM atau sebesar 37,04 persen dan selebihnya tidak tuntas. Dengan kata lain peserta didik kelas IPA pada umumnya tidak tuntas. Hasil tersebut dapat dilihat pada tabel 7 berikut ini. 
Tabel 7. Ketuntasan Belajar Fisika

\begin{tabular}{ccccc}
\hline Jumlah & \multicolumn{4}{c}{ Prestasi Belajar Fisika } \\
\cline { 2 - 5 } Siswa(org) & Tidak Tuntas (org) & $\mathbf{\%}$ & Tuntas (org) & $\%$ \\
\hline 135 & 85 & 62,96 & 50 & 37,04 \\
\hline
\end{tabular}

Sumber data SMA Kr Barana Rantepao Toraja Utara

$*)=($ peserta didik /total peserta didik)x $100 \%$

\section{Analisis korelasional}

Hasil korelasi antara gaya kognitif dengan prestasi belajar fisika dan kecerdasan emosional dengan prestasi belajar fisika menggunakan Rank Spearman. Pada awalnya data diuji menggunakan uji korelasional Product Moment Pearson, tetapi karena syarat data harus terdistribusi normal sedangkan data gaya kognitif tidak terdistribusi normal dan data pada penelitian ini berupa data ordinal maka data diuji menggunakan Rank Spearman (Sarwono, 2010).

Tabel 8. Uji Normalitas data Gaya Kognitif

\begin{tabular}{llr}
\multicolumn{2}{c}{ One-Sample Kolmogorov-Smirnov Test } \\
\hline $\mathrm{N}$ & & VAR00001 \\
Normal Parameters ${ }^{\mathrm{a}}$ & Mean & 135 \\
& Std. Deviation & 8.8741 \\
Most Extreme Differences & Absolute & 2.95344 \\
& Positive & .135 \\
& Negative & .135 \\
Kolmogorov-Smirnov Z & & -.058 \\
\hline Asymp. Sig. (2-tailed) & & 1.567 \\
\hline
\end{tabular}

a. Test distribution is Normal

Dari tabel 8, diketahui bahwa untuk data gaya kognitif tidak terdistribusi dengan normal karena nilai $\mathrm{p}=0,015<0,05$.

Uji korelasional gaya kognitif, kecerdasan emosional dengan prestasi belajar diganti menggunakan menggunakan Rank Spearman, yang hasil analisisnya dapat dilihat pada tabel 9, berikut,

Tabel 9. Korelasional menggunakan Rank Spearman

\begin{tabular}{lllrrr}
\hline & & $\mathrm{gk}$ & $\mathrm{Ke}$ & \multicolumn{1}{c}{$\mathrm{Pb}$} \\
\hline Rank Spearman & Gk & Correlation Coefficient & 1.000 & -.028 & $.257^{* *}$ \\
& & Sig. (2-tailed) &. & .751 & .003 \\
& $\mathrm{~N}$ & 135 & 135 & 135 \\
& $\mathrm{Ke}$ & Correlation Coefficient & -.028 & 1.000 & .053 \\
& & .751 &. & .541 \\
& Sig. (2-tailed) & 135 & 135 & 135 \\
& $\mathrm{~N}$ & $.257^{* *}$ & .053 & 1.000 \\
& $\mathrm{pb}$ & .003 & .541 &. \\
& Correlation Coefficient & 135 & 135 & 135 \\
& Sig. (2-tailed) & & & \\
& $\mathrm{N}$ & & & \\
\end{tabular}

**. Correlation is significant at the 0.01 level (2-tailed) 
Dari tabel 9, terlihat bahwa koefisien korelasi $r_{x y}=0,257$ dengan $p=0,003<0,05$ artinya ada hubungan yang signifikan antara gaya kognitif dan prestasi belajar fisika dengan arah postif yang berarti jika skor gaya kognitif meningkat maka prestasi belajar fisika juga meningkat dan jika skor gaya kognitif turun maka prestasi belajar fisika juga turun. Hubungan kecerdasan emosional dengan prestasi belajar dengan koefisien $r_{x y}=0,053$ dengan $p=0,541>0,05$. Berarti tidak ada hubungan yang signifikan antara kecerdasan emosional dengan prestasi belajar fisika. Artinya jika kecerdasan emosional naik atau turun tidak dapat ditentukan naik atau turunnya prestasi belajar fisika anak IPA di SMA Kr Barana Rantepao Toraja Utara. Karena tidak ditemukan hubungan yang signifikan antara kecerdasan emosional dengan prestasi belajar Fisika maka dilakukan analisis per aspek kecerdasan emosional dengan hasil sebagai berikut.

Tabel 10. Korelasi Intrapersonal dengan prestasi belajar fisika

Correlations

\begin{tabular}{lllrr}
\hline & & Intrapersonal & \multicolumn{1}{c}{ PB } \\
\hline Spearman's rho & Intrapersonal & Correlation Coefficient & 1.000 & -.039 \\
& & Sig. (2-tailed) &. & .657 \\
& & $\mathrm{~N}$ & 135 & 135 \\
& $\mathrm{~PB}$ & Correlation Coefficient & -.039 & 1.000 \\
& & Sig. (2-tailed) & .657 &. \\
& $\mathrm{~N}$ & 135 & 135 \\
\hline
\end{tabular}

Tabel 11. Korelasi Manajemen Stress dengan prestasi belajar fisika

Correlations

\begin{tabular}{|c|c|c|c|c|}
\hline & & & $\begin{array}{c}\text { Stress } \\
\text { Management }\end{array}$ & PB \\
\hline \multirow[t]{6}{*}{ Spearman's rho } & \multirow{3}{*}{$\begin{array}{l}\text { Stress } \\
\text { Management }\end{array}$} & Correlation Coefficient & 1.000 & .079 \\
\hline & & Sig. (2-tailed) & . & .361 \\
\hline & & $\mathrm{N}$ & 135 & 135 \\
\hline & \multirow[t]{3}{*}{ PB } & Correlation Coefficient & .079 & 1.000 \\
\hline & & Sig. (2-tailed) & .361 & \\
\hline & & $\mathrm{N}$ & 135 & 135 \\
\hline
\end{tabular}

Tabel 12. Korelasi Kemampuan adaptasi dengan prestasi belajar fisika

\begin{tabular}{|c|c|c|c|c|}
\hline \multicolumn{5}{|c|}{ Correlations } \\
\hline & & & Adabtability & $\mathrm{pb}$ \\
\hline \multirow[t]{6}{*}{ Spearman's rho } & Adabtability & Correlation Coefficient & 1.000 & .154 \\
\hline & & Sig. (2-tailed) & & .075 \\
\hline & & $\mathrm{N}$ & 135 & 135 \\
\hline & $\mathrm{pb}$ & Correlation Coefficient & .154 & 1.000 \\
\hline & & Sig. (2-tailed) & .075 & . \\
\hline & & $\mathrm{N}$ & 135 & 135 \\
\hline
\end{tabular}


Tabel 13. Korelasi General Mood dengan Prestasi Belajar Fisika

\begin{tabular}{clrr}
\multicolumn{2}{c}{ Correlations } & & \\
\hline & & General mood & \multicolumn{1}{c}{$\mathrm{pb}$} \\
\hline Spearman's rho General mood & Correlation Coefficient & 1.000 & -.013 \\
& Sig. (2-tailed) &. & .883 \\
& $\mathrm{~N}$ & 135 & 135 \\
$\mathrm{nb}$ & Correlation Coefficient & -.013 & 1.000 \\
& Sig. (2-tailed) & .883 &. \\
& $\mathrm{~N}$ & 135 & 135 \\
\hline
\end{tabular}

Dari hasil korelasional tiap aspek didapatkan korelasi yang juga menunjukkan tidak adanya hubungan signifikan antara tiap aspek dengan prestasi belajar fisika.

\section{PEMBAHASAN}

Dari hasil penelitian didapatkan ada hubungan yang signifikan antara gaya kognitif dengan prestasi belajar seperti pendapat Witkin. Menurut Witkin (1971) bahwa individu field independent lebih suka bekerja dari ciri kepribadian dan cenderung berpikir analitik, mengorganisasi materi pembelajaran menurut kepentingannya sendiri, merumuskan tujuan pembelajaran secara internal dan lebih mengutamakan motivasi internal yang menjadi ciri intelektualnya. Sehingga field independent dominan dalam sains fisika, biologi, matematika dan kimia. Individu field dependent lebih suka bersosialisasi dari ciri kepribadiannya dan cenderung berpikir global, sosial, mengikuti struktur materi pembelajarannya sesuai petunjuk dan lebih mengutamakan motivasi eksternal dari ciri intelektualnya. Sehingga field dependent lebih dominan dalam sains kemasyarakatan, konseling dan guru. Gaya kognitif anak IPA di SMA Kr barana 80 persen memiliki gaya kognitif cenderung ke IPS, anak IPA dengan gaya kognitf IPS akan berpengaruh terhadap prestasi belajar ini sesuai dengan hasil penelitian yang menemukan 62,96 peserta didik tidak tuntas dalam pelajaran fisika. Prestasi belajar fisika rendah karena anak-anak yang ada dikelas IPA memiliki gaya kognitif lebih cocok di IPS.

Penelitian ini menemukan bahwa tidak ada hubungan yang signifikan antara kecerdasan emosional dengan prestasi belajar fisika. Meskat (2011) mengatakan dari hasil penelitian kecerdasan emosional memiliki korelasi yang lemah terhadap prestasi belajar. Menurut Meskat (2011) untuk meningkatkan prestasi belajar lebih baik meningkatkan kemampuan kognitif siswa dengan kata lain kemampuan kognitif lebih berhubungan dengan prestasi belajar dibandingkan dengan kecerdasan emosional. Riani \& Farida (2001), memberikan pengertian kecerdasan emosional sebagai suatu kemampuan untuk mengerti emosi diri sendiri dan orang lain serta mengetahui bagaimana emosi diri sendiri terekspresikan untuk peningkatan maksimal secara etis sebagai kekuatan pribadi. Sains berkaitan dengan cara mencari tahu tentang alam secara sistematis, sehingga sains bukan hanya penguasaan kumpulan pengetahuan yang berupa fakta-fakta, konsep-konsep, atau prinsipprinsip saja tetapi juga merupakan suatu proses penemuan (Depdiknas, 2003).

Sebagai produk Fisika menghasilkan fakta, konsep, prinsip, hukum, rumus, teori dan model yang dapat digunakan oleh siswa untuk memahami dan mengembangkan ilmu pengetahuan itu sendiri. Sebagai proses fisika adalah pemahaman mengenai bagaimana informasi ilmiah dalam fisika diperoleh yang berkaitan dengan fenomena, dugaan, pengamatan, pengukuran, penyelidikan, 
dan publikasi (Collette dan Chiappetta, 1994). Kerja ilmiah yang menuntut cara berpikir dan cara bekerja secara ilmiahlah yang dibutuhkan dalam pembelajaran Fisika bukan bagaimana peserta didik mengenali emosinya dan emosi orang lain. Goleman(2000) menyatakan ada kecerdasan lain selain IQ yaitu kecerdasan Emosional. Dalam aspek-aspek yang terurai dalam kecerdasan emosional dan indikatornya terdiri dari aspek sosial sedangkan mata pelajaran fisika adalah sesuatu yang berhubungan dengan ilmu alam bukan ilmu sosial.

\section{KESIMPULAN}

Berdasarkan hasil penelitian dapat disimpulkan bahwa:

1. Ada hubungan yang signifikan antara gaya kognitif dengan prestasi belajar fisika dengan arah positif pada peserta didik IPA SMA Kr Barana rantepao Toraja Utara. Artinya jika skor gaya kognitif ditingkatkan maka prestasi belajar fisika juga meningkat dan jika skor gaya kognitif turun maka prestasi belajar fisika juga turun.

2. Tidak ada hubungan yang signifikan antara kecerdasan emosional dengan prestasi belajar fisika pada peserta didik IPA SMA Kr Barana rantepao Toraja Utara. Artinya jika kecerdasan emosional naik atau turun tidak dapat ditentukan hubungannya naik atau turunnya prestasi belajar fisika anak IPA di SMA Kr Barana Rantepao Toraja Utara.

\section{DAFTAR PUSTAKA}

Collette, Alfred T., dan Eugene L. Chiappetta. 1994. Science Instruction in The Middle and Secondary Schools. 2nd Edition. New York : Macmillan Pub.Co.

Davis, Mark. 2008. Tes EQ. Dela Pratasa.

Depdiknas, 2003 . Kurikulum Sains (IPA). Jakarta Pusat Kurikulum, Balitbang Dekdikbu RI.

Gardner, H. 1993. Frames of mind: The theory of multiple intelligences: Tenth anniversary edition. New York: Basic Books.

Goleman, D. (1995). Emotional Intelligence: Why It Can Matter More Than IQfor Character, Health and Lifelong Achievement. New York: Bantam Books.

.2000, Kecerdasan Emosi : Mengapa Emotional Intelligence Lebih Tinggi Daripada $I Q$, Alih Bahasa : T. Hermay, Jakarta: PT. Gramedia Pustaka Utama.

_. 2001, Emotional Intelligence Untuk Mencapai Puncak Prestasi, Alih Bahasa : Alex Tri K.W, Jakarta: PT. Gramedia Pustaka Utama.

Lourdusamy, A. 1994. Perbedaan gaya kognitif individu dan implikasinya terhadap pendidikan. Dalam: Siri Syarahan Perlantikan Profesor (1995/3), 5 Feb 1994, Pulau Pinang: Universiti Sains Malaysia.

Meskat. Maryam, 2011, The Relationship Between Emotional Intelligence and Academic Success, Journal of Technology \& Education, Vol. 5, No.3, Shahid Rajaee, Tehran: Teacher Training University.

Riani, A. L. \& Farida, H. 2001. Pengaruh Kompetensi Utama Kecerdasan Emosional dan Self Efficacy Terhadap Kenyamanan Supervisor dalam Melakukan penilaian Kinerja. http:// mm.uns.ac.id/jurnal. php?ket=detail \&did=488.html. 17 Desember 2012 
Salovey dan Mayer. 1990. Emotional Inteligence. Baywood Publisihing.co.,Inc. http:// www.unh.edu/emotional intelligence/EI\%20Assets/Reprints...EI\%20Proper/ EI1990\%20Emotional\%20Intelligence.pdf. September 2012.

Salovey, dan Mayer. 1997. What is emotional intelligence? In P. Salovey \& D. J. Sluyter (Eds.), Emotional development and emotional intelligence: Educational implications . New York: Basic Books.

Slameto. 2003. Belajar dan faktor-faktor yang mempengaruhinya. Jakarta : PT Rineka Cipta. . 2002. Persepsi siswa terhadap peran guru pembimbing dalam hubungannya dengan kemandirian belajar dan prestasi belajar siswa SMU unggulan (Studi di SMU Laboratorium UKSW Salatiga) Tesis, Universitas Negeri Semarang

Surya, Mohammad. 2004. Psikologi Pembelajaran dan Pelajaran. Bandung: Pustaka Bani Quarisy.

Winkel, W.S. 1987. Psikologi Pengajaran. Jakarta: PT Gramedia.

Witkin, H.A., Oltman, P.K Raskin dan Karp, S.A. 1971. A manual foe embedded figure test. Palo Alto, Calif: Consulting Psychologists Press.

Witkin, H.A., Moore, C. A. Goodenough, D. R. Dan Cox, P.W. 1977. Field dependent and field independent conitive style and their educational implications. Review of Education Research.

Widyastuti, E., \& Kuswardani, I. 2008. Hubungan Antara Harga Diri Dan Prestasi Belajar Fisika Pada Siswa STM. Psikohumanika, 1(1), 22-29. Surakarta: Fakultas Psikologi Universitas Setia Budi. 
Satya Widya, Vol. 28, No.2. Desember 2012 